\title{
ROAD SAFETY SYSTEM IN POLAND
}

\section{SYSTEM BEZPIECZEŃSTWA TRANSPORTU DROGOWEGO W POLSCE}

\author{
Joanna Żukowska ${ }^{1}$, Marcin Budzyński \\ (1) Gdańsk University of Technology, Faculty of Civil \\ and Environmental Engineering \\ Politechnika Gdańska, Wydzial Inżynierii Lądowej i Środowiska \\ 80-952 Gdańsk ul. Narutowicza 11 \\ (2) Gdańsk University of Technology, Faculty of Civil \\ and Environmental Engineering \\ Politechnika Gdańska, Wydział Inżynierii Lądowej i Środowiska \\ 80-952 Gdańsk ul. Narutowicza 11 \\ e-mails: (1) joanna.zukowska@wilis.pg.gda.pl, (2)mbudz@pg.gda.pl
}

\begin{abstract}
The main objective of the paper is to present crucial for road safety improvement elements of the diagnosis of safety state and safety system in Poland, which could be the part of the activities of ZEUS Project. The estimation of the diagnosis was made by the comparison with the standards from those countries, which are regarded as leaders in safety.
\end{abstract}

Key words: road traffic, system, safety, casualties

Streszczenie: Celem niniejszego artykułu jest przedstawienie kluczowych dla poprawy brd elementów diagnozy stanu i systemu bezpieczeństwa w Polsce, które jednocześnie mogłyby wejść w zakres działań objętych Projektem ZEUS. Ocenę diagnozy wykonano poprzez porównanie $\mathrm{z}$ wzorcami z tych krajów, które od lat uważa się za liderów w zakresie bezpieczeństwa.

Slowa kluczowe: ruch drogowy, system, bezpieczeństwo, ofiary wypadków 


\section{ROAD SAFETY SYSTEM IN POLAND}

\section{Introduction}

For the last couple of years of free development of Polish economy the need for road transport has risen a lot and the predictions show that it will still be. Unfortunately, neither preventive actions nor development of infrastructure have not kept up satisfactorily with the pace of dynamic development of motorization which resulted in serious social and economical loss [1].

Although since 1991 the trend of the number of fatalities on the roads in Poland has been decreasing and we have noticed significant improvement, for the last couple of years we have observed its stagnation. It means a necessity to activate new and effective methods of preventive and recovery actions, which have been used in the countries with the highest index of road safety.

The main objective of the paper is to present crucial for road safety improvement elements of the diagnosis of safety state and safety system in Poland, which could be the part of the activities of ZEUS Project. The estimation of the diagnosis was made by the comparison with the standards from those countries, which are regarded as leaders in safety. Strengths and weaknesses of the existing system and state have been stated showing the possibilities for strengthening the second ones by using already good and checked practices abroad. Only those solutions have been taken into account which in Polish conditions are possible to be introduced, having resigned from those which would be difficult and unreal.

\section{Diagnosis of the state of the road safety in Poland}

For the last 5 years 29 thousand people have been killed and 335 thousand have been injured in road accidents in Poland. The cost of road accidents has amounted to 145 milliard PLN, i.e. 29 milliard a year. The most frequent types of accidents in the analyzed period of time were: driving onto or a tree, side collisions, head-on collisions. 
We can distinct such groups of high risk as: pedestrians, young drivers, children and cyclists (Fig. 1). The index of the fatalities among those unprotected traffic participants amounts to 6,8/100 thousand citizens and is the highest in Europe.

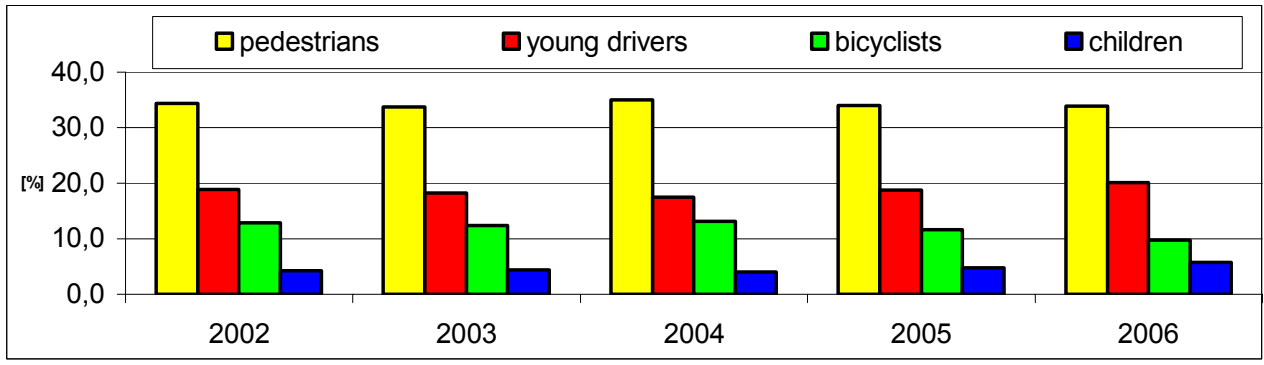

Fig. 1 Main of hazard groups

For the main road safety problems in our country we regard such elements as: dangerous activity of road traffic participants and low quality of road infrastructure [3]. Dangerous activities are: excessive speed, insobriety of the drivers, low level of using safety equipment, keeping close distance, inobservance of traffic regulations and lack of respect towards other drivers. Poor quality of road infrastructure is: "hard" (unforgiving) road environment, transit ways via cities and places, intersections and zebra crossings (Fig. 2).

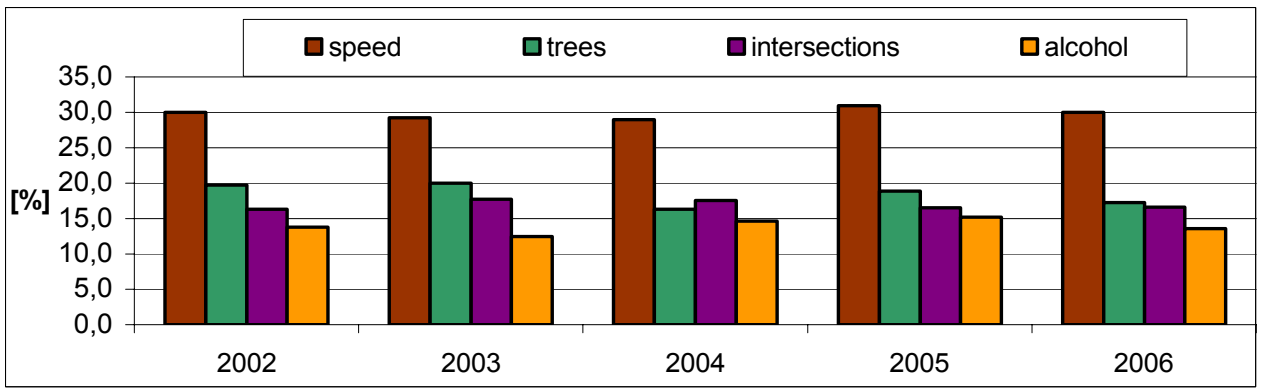

Fig. 2 Main of selected road safety problems

\section{Diagnosis of the Polish road safety system}

The improvement of the road safety depends mainly on good organization and functioning of the transportation system. In Poland the vast majority of the elements of the road safety system already exist or their implementation 
is being planned. Yet still many of its aspects need to be reorganized or amended. The first group includes the following items:

- regional and local activity growth,

- the creation and implementation of the monitoring system aimed at particular performance of the traffic participants in all voivodeships,

- the design of the curriculum for the regional and central staff training programme,

- financial support of the central and regional activity,

- increase in the social awarness of the traffic dangers,

- the rise of the NGOs involvement in the road safety movement.

The items that need to be reorganized and implemented are as follows:

- adequate number of trained staff and leaders in the local government institutions, on various administrative levels,

- proper legal regulations in the range of effective structures and auditing in the road safety organization,

- automotive education system at schools,

- availability of local data bases on the traffic events used for safety analysis and the monitoring of programme implementation,

- the involvement of media: press, radio and television to promote good traffic performance patterns,

- scientific support.

\section{The system's strengths and weaknesses identification}

The identification of the road safety system's strengths and weaknesses in Poland has been based on the analysis of the internal and the external factors that have impact on the system (currently and in the future) and modify its development and operational strategy. The system's internal factors analysis and their evaluation have enabled us to identify its strengths and weaknesses. The specified strengths have been mainly the already functioning elements of the system, such as:

- automotive education (school activities, cooperation with the police,

- road safety structures (National RS Council, rs programmes, locally implemented traffic projects/designs, audit, scientific research),

- traffic inspection and supervision (Road Transport Inspectorat, increased automatization of supervision),

- road infrastructure (ideas and programmes for the municipal safety as well as national road safety improvement, pilotage programmes realization) 
- road rescue (Rescue Party Centres, road rescue training centers, skilled rescue teams).

The weaknesses of the system have been all the factors that make it difficult to operate and thus decrease the organizational effectiveness and the means of the system management such as:

- system organization (the lack of audit, the lack of leaders, incomplete local road safety programmes, the lack of qualified staff in many institutions, the lack of local databases, weak supervision of the diagnostic centres, the lack of prosecutor teams for traffic accidents cases, the lack of involvement of the insurance companies, insufficient aid for the victims and their families), - education (insufficient staff training, weak equipment at schools, the lack of training infrastructure, bad driving schools, unused potential of the impact of media and the Church),

- traffic inspection and supervision (traditional methods, insufficient equipment, shortages in staff),

- road infrastructure (the lack of complex network for fast traffic, the shortcomings of the existing infrastructure, the lack of protection over fragile traffic participants),

- the road rescue (the lack of equipment, the municipal road network not adjusted to immediate rescue)

The external factors are the circumstances that influence the chances and dangers in the system functioning. The chances depend on the established position, resources, skills and competence. They include:

- national and local road safety programmes and their implementation,

- the pressure of the EU transportation policy,

- the financial support of the road network development,

- the legal regulations regarding the driving time limits and the drivers' qualifications,

- development and modernization of the fast traffic road network,

- the increase in the public transportation application,

- the spread in road safety awarness in society.

The above category consists also of dangers to the functioning of the system such as:

- the lack of appropriate rules and regulations regarding the structures, audit, automotive education at schools, penalization,

- poor automotive education curricula at schools,

- insufficient training system in driving instruction, 
- the lack of financial support from the budget,

- the lack of supplementary equipment for planning, design and road exploitation in accordance with road safety requirements,

- a weak involvement of media and the Church,

- incompetence of a part of the decision-making authorities.

The internal and external factors analysis indicates that our road safety system is in possession of many strengths, but it also has a number of weaknesses. Therefore, in order to efficiently implement the road safety improvement process, it is a priority to solve several essential problems such as speed inspection, young drivers, drunk driving, databases of road accidents and scientific research.

\section{Possibilities of system improvement}

Among the road safety system factors that need to be improved there are ones already successfully rationalized abroad. Below there is a brief description of some of them.

Speeding. The experience in acting to prevent excessive speeding so far has shown that the mere educational activity is not able to cause significant improvement in drivers' behaviour [5]. It is necessary to apply parallel inspection means aimed at the increased likelihood of being checked and punished for breaking traffic regulations in the drivers mind. At present the EU countries use various methods of speed inspection. It has been very successful to introduce an automatic speed inspection and penalization system in France, for instance. In Germany it is believed that the most effective solution is the speed inspection on the tracts along which there are posters highlighting the dangers of injuries and death caused by excessive speeding.

Young drivers. The first conclusion that appears after analyzing the scientific research reports is that it is necessary to introduce some operational limits for young drivers. The limits should be gradually reduced along with the gained experience, knowledge and the monitored traffic performance - accident and penalty rate. The research indicates that the full traffic maturity is achieved after five years of driving practice [2]. Undoubtedly a novum are the attempts to involve the families into the process. It is one of the ways to decrease the anonymity of the driver. There 
is a Canadian project that obliges car owners to stick on the rear a telephone number to a center which intervenes immediately in case a driver behaves in a dangerous manner. The center receives a description together with the place of the event and the vehicle number and then informs the car owner about the young driver's behaviour. The awarness of being under social supervision significantly influences the correctness of young drivers.

Research. One of the main road safety challenges in the EU is the creation of a common, independent base that would allow collecting data on road events within EU as well as information on safety and the activities that support it, i.e. the creation of a road safety observatory. The information should be available for the people actively dealing with road safety matters as well as the whole society. Its objectives depend on the level of performance on the European, state or regional ground, yet there are some common features characterizing these institutions. A road safety observatory is a scientific body conducting a systematic observation and research in the domain of safety. A particular emphasis is put on the formulation and the distribution of the knowledge so that it is easily available and clear not only to the scientific world and experts but also to the decision-making authorities [4].

Database. The comparison of the particular databases - the Polish SEWIK, the European CARE and the SafetyNet project enables to identify the differences and shortages in our system and to show the direction of changes. The necessity to adjust the Polish system to the EU requirements leads to better quality of data base, and consequently better road safety analysis. In the process it is advised to apply the experiences of the Expert Team CARE, to modify the range and the procedures in data collection, introduce the procedures in the data verification as well as rationalize the accident localization methods [6].

\section{Conclusions}

To sum up, the above diagnosis of the road safety condition and system clearly indicates the crucial challenges aimed at rationalization of road safety in Poland. Our country has its specific problems (for example unprotected traffic participants), or the problems common to other countries such as speeding or incompatibility of road accident database with other 
European databases. The paper has presented some possible rationalization objectives of the road safety system within the discussed areas.

The Integrated Transport Safety System, which is the item of the three years research project called ZEUS should take the specic Polish road safety problems into consideration and develop the prevention activites that have been effectively implemented abroad.

\section{Bibliography}

1. EC (European Commission). White Paper. European transport policy for 2010: time to decide. Brussels, Belgium. 2001.

2. ETSC (European Transport Safety Council) 1999. Police enforcement strategies to reduce traffic casualties in Europe

3. GAMBIT 2005: Krajowy Program Bezpieczeństwa Ruchu Drogowego. Ministerstwo Infrastruktury. Warszawa.

4. OECD: Road safety principles and models. Road Transport Research. OECD Publication. Paris, 1996.

5. TRB 1998: Managing Speed. Review of current practice for setting and enforcing Speer limits. Transportation Research Board. National Research Council. Washington DC.

6. Zielińska A.: Polska baza danych o wypadkach drogowych na tle standardów europejskich. Międzynarodowe Semianirum BRD GAMBIT 2006. Politechnika Gdańska. 2006. 


\section{SYSTEM BEZPIECZEŃSTWA TRANSPORTU DROGOWEGO W POLSCE}

\section{Wprowadzenie}

W ciagu kilkunastu lat swobodnego rozwoju polskiej gospodarki bardzo wzrosło zapotrzebowanie na transport drogowy, prognozy wskazują, że nadal będzie ono rosło. Niestety, ani działania prewencyjne, ani rozbudowa infrastruktury, dotychczas nie nadążały $\mathrm{w}$ zadowalającym stopniu za dynamicznym rozwojem motoryzacji, skutkiem tego są poważne straty społeczne i ekonomiczne [1]. Pomimo iż od 1991 roku trend liczby zabitych w ruchu drogowym w Polsce jest malejący i odnotowaliśmy w tym zakresie znaczącą poprawę, od kilku lat z niepokojem obserwujemy jego stagnację. Oznacza to konieczność uruchomienia nowych, skutecznych metod działań prewencyjnych i ratowniczych, takich, które sprawdziły się w krajach o najwyższych wskaźnikach bezpieczeństwa ruchu drogowego.

Celem niniejszego artykułu jest przedstawienie kluczowych dla poprawy brd elementów diagnozy stanu i systemu bezpieczeństwa w Polsce, które jednocześnie mogłyby wejść w zakres działań objętych Projektem ZEUS. Ocenę diagnozy wykonano poprzez porównanie z wzorcami z tych krajów, które od lat uważa się za liderów w zakresie bezpieczeństwa. Wykazano mocne i słabe strony istniejącego stanu i systemu bezpieczeństwa w Polsce, wskazując na możliwości wzmocnienia tych drugich właśnie poprzez korzystanie $\mathrm{z}$ dobrych i sprawdzonych zagranica praktyk. Uwzględniono jednocześnie jedynie takie rozwiązania, które w warunkach naszego kraju są możliwe do wprowadzenia $\mathrm{w}$ najbliższym czasie, rezygnując $\mathrm{z}$ rozwiązań, których realizacja byłaby z różnych powodów nierealna.

\section{Diagnoza stanu bezpieczeństwa ruchu drogowego w Polsce}

W ostatnich pięciu latach w wypadkach drogowych w Polsce śmierć poniosło 29 tys. osób, rannych było 335 tys., a koszty zdarzeń drogowych wyniosły prawie $145 \mathrm{mld} \mathrm{zl}$, tj. 29 mld rocznie. W badanym okresie najczęstszymi rodzajami wypadków były: najechania na pieszego, zderzenia boczne, zderzenia czołowe i najechania na drzewo. Na podstawie danych 
o poszkodowanych uczestnikach wyłonić można następujące grupy wysokiego ryzyka: piesi, młodzi kierowcy, dzieci i rowerzyści (rys. 1). Wskaźnik ofiar śmiertelnych wśród tzw. niechronionych uczestników ruchu wynosi 6,8 na 100 tys. mieszkańców i jest najwyższy w Europie.

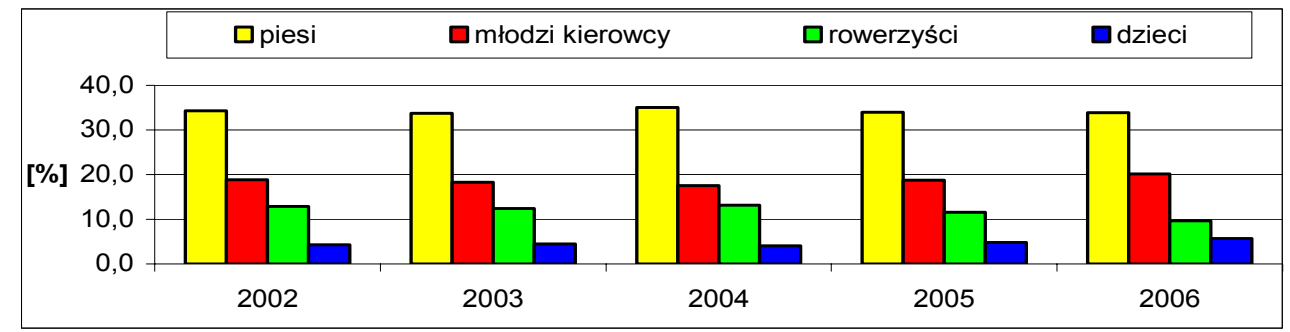

Rys. 1 Gtówne grupy ryzyka w ruchu drogowym

Za główne problemy brd w naszym kraju uważa się: niebezpieczne zachowania uczestników ruchu i niską jakość infrastruktury drogowej [3]. Niebezpieczne zachowania to przede wszystkim: nadmierna prędkość jazdy, nietrzeźwi użytkownicy dróg, niski stopień stosowania urządzeń bezpieczeństwa, jazda $\mathrm{w}$ zbyt bliskiej odległości, nieprzestrzeganie przepisów ruchu i brak poszanowania praw innych uczestników ruchu. Niska jakość infrastruktury drogowej to między innymi: „twarde” otoczenie drogi, przejścia dróg tranzytowych przez miasta i miejscowości, skrzyżowania i przejścia dla pieszych (rys. 2).

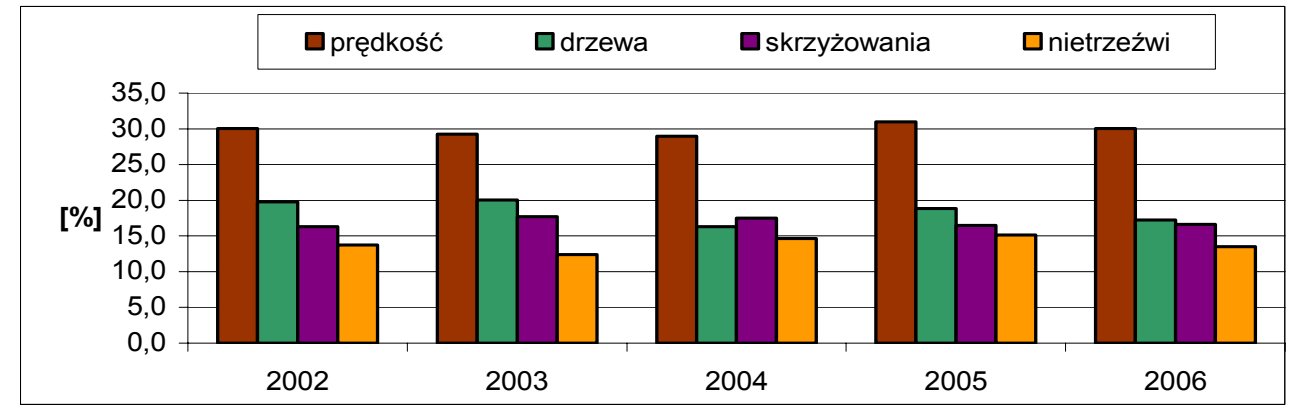

Rys. 2 Wybrane główne problemy brd

\section{Diagnoza systemu bezpieczeństwa ruchu drogowego w Polsce}

Efektywna i skuteczna realizacja procesu poprawy bezpieczeństwa ruchu drogowego zależy w głównej mierze od dobrego funkcjonowania systemu brd. W Polsce większość z elementów tego systemu już istnieje lub też ich wdrożenie jest planowane. Ciągle jednak wiele składników systemu wymaga zorganizowania lub usprawnienia. Do grupy elementów, które już funkcjonują, lub są wdrażane należą m.in.: 
- zwiększenie aktywności na poziomie regionalnym i lokalnym,

- budowę i wdrożenie systemu monitorowania wybranych zachowań uczestników ruchu drogowego we wszystkich województwach,

- przygotowanie programu szkolenia kadr na poziomie centralnym i regionalnym,

- finansowe wspieranie działań centralnych i regionalnych,

- wzrost świadomości społecznej w zakresie zagrożeń związanych $\mathrm{z}$ ruchem drogowym,

- wzrost zaangażowania organizacji pozarządowych w działania na rzecz brd.

Do elementów, które wymagają usprawnienia lub wdrożenia należą m.in.:

- liderów i dostatecznej ilości przeszkolonej kadry w instytucjach rządowych, samorządowych i sektorowych, na poziomie krajowym, wojewódzkim i powiatowym,

- odpowiednich uregulowań prawnych w zakresie organizacji skutecznych struktur oraz audytu brd,

- systemu edukacji motoryzacyjnej w szkołach,

- lokalnych baz danych o zdarzeniach drogowych dostępnych dla analiz brd i monitorowania realizacji programów,

- zorganizowanego wsparcia prasy, radia i telewizji, propagowania dobrych wzorców,

- wsparcia naukowego.

\section{Identyfikacja mocnych i słabych stron systemu}

W identyfikacji mocnych i słabych stron systemu bezpieczeństwa transportu drogowego w Polsce pomocną była analiza oparta na założeniu, że czynniki wewnętrzne i zewnętrzne, warunkujące funkcjonowanie systemu (obecnie i w przyszłości), wywierają pozytywny bądź negatywny wpływ na jego możliwości rozwojowe i strategię działania. Analiza i ocena czynników wewnętrznych funkcjonowania systemu pozwoliła na zidentyfikowanie jego atutów i słabości. Do atutów zaliczono głównie te elementy systemu, które w stanie obecnym już funkcjonuja, jak np.:

- edukacja motoryzacyjna (np.: działania w szkołach, współpraca z Policja, Wojewódzkimi Ośrodkami Ruchu Drogowego),

- struktury brd (np.: Krajowa Rada BRD, programy brd, miejscowo wprowadzany jest audyt projektów drogowych, badania naukowe),

- kontrola i nadzór nad ruchem (np.: działanie Inspekcji Transportu Drogowego, zwiększenie automatyzacji nadzoru), 
- infrastruktura drogowa (np.: koncepcje i programy poprawy bezpieczeństwa w miastach oraz na drógach krajowych i wojewódzkich, realizacja projektów pilotażowych),

- ratownictwo drogowe (np.: Centra Ratownictwa Medycznego, ośrodki szkolenia ratowników drogowych, przeszkoleni ratownicy).

Do słabości systemu brd zaliczono wszystkie te elementy, które utrudniaja działania, wpływając na niską sprawność organizacyjną i możliwości zarządzania systemem, takie jak:

- organizacja systemu (brak audytu brd, brak liderów brd, brak części wojewódzkich i powiatowych programów brd, brak przeszkolonej kadry w wielu instytucjach, brak powiatowych i gminnych baz danych, słaba kontrola stacji diagnostycznych, brak zespołów prokuratorskich do spraw wypadków drogowych, brak zaangażowania towarzystw ubezpieczeniowych, słaba pomoc ofiarom i ich rodzinom),

- edukacja (braki w szkoleniu kadr, słabe wyposażenie szkół, brak miasteczek ruchu drogowego, słabe szkoły nauki jazdy, nie wykorzystane możliwości oddziaływania mediów i kościoła).

- kontrola i nadzór nad ruchem (tradycyjne metody wykrywania przestępstw w ruchu drogowym, braki w sprzęcie, braki kadrowe).

- infrastruktura drogowa (brak rozbudowanej sieci dróg ruchu szybkiego, mankamenty istniejącej infrastruktury drogowej, brak ochrony słabych uczestników ruchu).

- ratownictwo drogowe (braki sprzętowe, nieprzystosowane do szybkiej akcji ratowniczej sieci uliczne w większości miast).

Uwarunkowania zewnętrzne to te okoliczności, które wpływają na szanse i zagrożenia funkcjonowania systemu. Szanse jego rozwoju zależą od wypracowanej pozycji, posiadanych zasobów, umiejętności i kompetencji. Do takich szans należy zaliczyć:

- krajowy i wojewódzkie programy brd i ich realizacja,

- presja polityki transportowej Unii Europejskiej,

- wsparcie finansowe na rozbudowę układu drogowego,

- uregulowania prawne związane z czasem pracy i kwalifikacjami kierowców,

- modernizacja i rozwój sieci dróg ruchu szybkiego,

- zwiększenie udziału transportu zbiorowego w podróżach,

- zwiększający się poziom wiedzy o brd w społeczeństwie.

W tym zakresie za zagrożenia funkcjonowania sytemu uznać należy następujące czynniki zewnętrzne: 
- brak odpowiednich uregulowań prawnych w zakresie: struktur, audytu, edukacji motoryzacyjnej w szkołach, represji,

- braki w programie nauczania edukacji motoryzacyjnej w szkołach,

- niedoskonały system szkolenia kandydatów na kierowców,

- brak wsparcia finansowego ze środków budżetowych,

- brak materiałów pomocniczych do planowania, projektowania i eksploatacji dróg i ulic z punktu widzenia brd,

- słaba rola mediów i kościoła,

- niekompetencja części decydentów.

Analiza czynników wewnętrznych i zewnętrznych wskazuje, że nasz system brd posiada dość duży zasób atutów, ale również wiele słabości. Dlatego też dla efektywnej i skutecznej realizacji procesu poprawy bezpieczeństwa ruchu drogowego należy w pierwszej kolejności zająć się rozwiązaniem kilku podstawowych kwestii m.in. dotyczących nadzoru prędkości, problemu młodych kierowców, jazdy pod wpływem alkoholu, baz danych o wypadkach drogowych czy badań naukowych.

\section{Kierunki usprawnienia systemu}

Wśród elementów systemu bezpieczeństwa transportu drogowego wymagających usprawnienia znajdują się takie, które w skutecznie udało się rozwiązać zagranicą. Poniżej przedstawiono krótką charakterystykę kilku wybranych.

Nadmierna prędkość. Dotychczasowe doświadczenia w działaniach na rzecz zmniejszenia stopnia przekraczania dozwolonych prędkości wskazują, że same działania edukacyjne nie są $w$ stanie spowodować znaczących zmian w zachowaniach kierowców [5]. Konieczne są więc równoległe działania kontrolne, których głównym celem powinno być wytworzenie $\mathrm{u}$ kierowców przekonania o wysokim prawdopodobieństwie bycia zatrzymanym i ukaranym przez policję za naruszenia prawa. Obecnie w krajach UE są stosowane różne metody kontroli prędkości. Na przykład we Francji, w ostatnich latach osiagnnięto niebywały sukces poprzez zastosowanie automatycznego systemu kontroli prędkości i penalizacji kierowców. Niemcy zaś stoją na stanowisku, że najbardziej efektywnym rozwiązaniem jest kontrola prędkości na trasie, wzdłuż której są umieszczone plakaty informujące o zagrożeniu utraty zdrowia i życia wskutek nadmiernej prędkości.

Młodzi kierowcy. Pierwszą tezą która nasuwa się po lekturze raportów $\mathrm{z}$ badań naukowych prowadzonych $\mathrm{w}$ różnych krajach świata, jest to że konieczne są pewne ograniczenia operacyjne dla młodych kierowców. 
Powinny on potem być zmniejszane w miarę rosnącego doświadczenia i poprawności zachowań $\mathrm{w}$ ruchu drogowym, mierzonymi bezwypadkową i bezmandatową jazdą. Badania bowiem wykazały, że dopiero po około 5 latach prowadzenia pojazdu osiagamy dojrzałość w zachowaniu się w ruchu drogowym [2]. Niewątpliwym novum są próby jeszcze szerszego angażowania rodziny do współpracy. Poszukuje się przede wszystkim sposobu zmniejszenia anonimowości kierowcy. Jednym z nich jest projekt kanadyjski, polegający na naklejaniu na tylnej szybie numeru centrali, pod który można zadzwonić natychmiast po dostrzeżeniu niebezpiecznego zachowania się kierowcy. Podając w centrali krótki opis zachowania się kierowcy, miejsce zdarzenia oraz numer samochodu, powodujemy, że jego właściciel otrzyma opis zachowania się młodego kierowcy, któremu udostępnił swoje auto. Ta świadomość „bycia pod społeczną kontrolą” znacząco wpływa na zmianę zachowań młodych kierowców.

Badania naukowe. Jednym $\mathrm{z}$ ważniejszych europejskich wyzwań w tym zakresie jest utworzenie wspólnej niezależnej platformy, pozwalającej na gromadzenie razem zarówno danych o zdarzeniach drogowych w UE, jak i informacji o bezpieczeństwie i działaniach je wspierających, czyli stworzenie tzw. obserwatorium brd. Odbiorcami tych informacji mają być zarówno osoby czynnie zajmujące się bezpieczeństwem, jak i ogół społeczeństwa. Zadania i cele obserwatoriów bezpieczeństwa zależą od poziomu jego działania: europejskiego, krajowego czy regionalnego, jednak można wyróżnić wspólne cechy łączące te instytucje. Obserwatorium brd to palcówka naukowa, w której prowadzi się systematyczne obserwacje i badania w zakresie bezpieczeństwa. Szczególny nacisk kładzie się na formułowanie i rozpowszechnianie wiedzy, tak by była ona łatwo dostępna i zrozumiała nie tylko dla naukowców i ekspertów, ale przede wszystkim decydentów [4].

Bazy danych. Porównanie polskiej bazy danych SEWIK i europejskiej bazy CARE oraz projektu SafetyNet pozwala na określenie różnic i braków naszego systemu i wskazanie kierunków zmian. Konieczność dostosowania polskiego systemu do wymagań UE stwarza warunki i szanse na podniesienie jakości bazy danych, a co z tym związane jakości analiz brd. W procesie tym należy m.in.: skorzystać z doświadczeń Grupy Ekspertów CARE, zmodyfikować zakres oraz procedury zbierania danych, wprowadzić procedury weryfikacji danych, zmodyfikować metodę określania lokalizacji wypadków [6]. 


\section{Wnioski}

Podsumowując, przedstawiona diagnoza stanu oraz systemu brd jasno wskazuje podstawowe wyzwania $\mathrm{w}$ zakresie poprawy bezpieczeństwa w Polsce. Nasz kraj ma swoje specyficzne problemy (np. niechronieni uczestnicy ruchu drogowego), ma również i takie, które obserwuje się również $w$ innych krajach. Jest to przykładkowo problem nadmiernej prędkości czy niespóności bazy danych o wypadkach z innymi europejskimi bazami. W referacie wskazano kilka możliwych usprawnień systemu brd w wybranych obszarach.

Zintegrowany System Bezpieczeństwa Transportu, którego sposób funkcjonowania $\mathrm{W}$ przyszłości jest przedmiotem 3 letniego projektu badawczego ZEUS powinien brać pod uwage specyfikę polskich problemów brd oraz możliwość ich eliminacji poprzez czerpanie z bogatych doświdczeń zagranicznych.

ŻUKOWSKA JOANNA Ph.D. Eng. Adiunct at the Faculty of Civil and Environmntal Engineering in Gdansk University of Technology. Specialisation: road traffic engineering, road safety, transportation policy.

BUDZYŃSKI MARCIN, Adiunct at the Faculty of Civil and Environmntal Engineering in Gdansk University of Technology. Specialisation: road traffic engineering, road safety, economics of transport. 
